\title{
Hepatitis C virus and human T-lymphotropic virus coinfection: epidemiological, clinical, laboratory and histopathological features
}

\author{
Coinfecção vírus da hepatite C-vírus linfotrópico de células T humanas: \\ aspectos epidemiológicos, clínicos, laboratoriais e histopatológicos
}

\author{
Flávio Augusto Pádua Milagres ${ }^{1}$, Maria Irma Seixas Duarte ${ }^{2}$, \\ Ana Teresa Viso ${ }^{1}$ and Aluisio Cotrim Segurado ${ }^{1}$
}

\begin{abstract}
Twenty-four hepatitis C virus patients coinfected with human T-lymphotropic virus type 1 were compared with six coinfected with HTLV-2 and 55 with HCV alone, regarding clinical, epidemiological, laboratory and histopathological data. Fischer's discriminant analysis was applied to define functions capable of differentiating between the study groups (HCV, HCV/HTLV-1 and HCV/HTLV-2). The discriminant accuracy was evaluated by cross-validation. Alcohol consumption, use of intravenous drugs or inhaled cocaine and sexual partnership with intravenous drug users were more frequent in the HCV/HTLV-2 group, whereas patients in the HCV group more often reported abdominal pain or a sexual partner with hepatitis. Coinfected patients presented higher platelet counts, but aminotransferase and gamma-glutamyl transpeptidase levels were higher among HCV-infected subjects. No significant difference between the groups was seen regarding liver histopathological findings. Through discriminant analysis, classification functions were defined, including sex, age group, intravenous drug use and sexual partner with hepatitis. Cross-validation revealed high discriminant accuracy for the HCV group.
\end{abstract}

Key-words: Hepatitis C virus. Human T-lymphotropic virus type 1. Human T-lymphotropic virus type 2. Epidemiological studies. Discriminant analysis.

\section{RESUMO}

Compararam-se 24 pacientes coinfectados pelos vírus da hepatite C/vírus linfotrópico de células T humanas do tipo 1 com 6 coinfectados por VHC/ HTLV-2 e 55 infectados pelo VHC, no tocante a dados clínico-epidemiológicos, laboratoriais e histopatológicos. A análise discriminante de Fischer foi utilizada para definir funções capazes de diferenciar os grupos de estudo (VHC, VHC/HTLV-1 e VHC/HTLV-2). A acurácia discriminatória foi avaliada pelo por validação cruzada. 0 uso de álcool, drogas endovenosas, cocaína inalatória e a parceria sexual com UDEV foram mais frequientes no grupo VHC/HTLV-2, enquanto queixa de dor abdominal e parceiro sexual com hepatite predominaram no grupo VHC. Os coinfectados apresentaram número maior de plaquetas, enquanto as aminotransferases e a gamaglutamiltranspeptidase foram mais altas no grupo VHC. Não houve diferença entre os grupos à análise histopatológica do fígado. Por análise discriminante definiram-se funções classificatórias, incluindo as variáveis sexo, faixa etária, uso de drogas endovenosas e parceiro sexual com hepatite, com acurácia discriminante alta para o grupo VHC.

Palavras-chaves: Vírus da hepatite C. Vírus linfotrópico de células T humanas do tipo 1. Vírus linfotrópico de células T humanas do tipo 2. Estudos epidemiológicos. Análise discriminante.

\footnotetext{
1. Department of Infectious Diseases, School of Medicine, University of São Paulo, São Paulo, SP, Brazil. 2. Department of Pathology, School of Medicine, University of São Paulo, São Paulo, SP, Brazil.

Financial support: The present study was partially funded by grants from CAPES and CNPq (Brazilian Ministries of Education and of Science and Technology).

Address to: Dr. Aluisio Cotrim Segurado. Dept. of Infectious Diseases, School of Medicine, University of São Paulo. Av. Dr. Enéas de Carvalho Aguiar 470, 05403-000 São Paulo, SP.

Tel: 5511 3066-7347; Fax: 5511 3068-9071

e-mail: segurado@usp.br

Received in 22/01/2009

Accepted in 20/07/2009
}

Since hepatitis C virus (HCV) and human T-cell lymphotropic virus type 1 (HTLV-1) and type 2 (HTLV-2) share their transmission means, the occurrence of coinfections is expected in populations at higher risk of sexual or blood-borne viral acquisition. In fact, HCV/HTLV coinfections have been described as frequent among intravenous drug users (IDUs) ${ }^{24}$, hemophiliacs ${ }^{5}$ and individuals who report unsafe sexual practices ${ }^{28}$.

However, the epidemiological and clinical features of HCV/ HTLV coinfected individuals have been overlooked. In-depth investigation of these characteristics may reveal particularly 
relevant information about the risk of viral acquisition, as well as about the pathogenetic impact of coinfection on HCV and/or HTLVassociated disease development. So far, virus-host interactions in coinfected individuals have been reported to be associated with dysfunctional cell immune response, which might impair HCV clearance and lead to accelerated progression of HCV liver disease $^{12} 2729$.

To improve our understanding of HCV/HTLV-1 and HCV/HTLV-2 coinfections, in the present study we compared sociodemographic features, variables relating to exposure to these viral infections, clinical and laboratory abnormalities, and liver histological characteristics among three groups of patients: HCV-infected individuals and HCV infected individuals presenting coinfection with either HTLV-1 or HTLV-2.

\section{MATERIAL AND METHODS}

Patient selection. For this cross-sectional study, we selected patients who were seen at specialized outpatient services that provide counseling and follow-up care for HCV and HTLV patients at Hospital das Clinicas, School of Medicine, University of São Paulo, between January 1993 and August 2005. For the HCV/HTLV1 and HCV/HTLV-2 groups, we enrolled adults who were diagnosed as HCV/HTLV-1 or HCV/HTLV-2 coinfected, respectively. The HCV group consisted of HCV-infected patients who presented neither HTLV-1 nor HTLV-2 infection. Patients with serological biomarkers indicating previous hepatitis B virus (HBV) infection, HIV coinfected individuals and transplant recipients were excluded.

The diagnosis of HCV infection was based on the seroreactivity of third-generation enzyme immunoassays (Murex Biotech, Baijing United Biomedical, and Embrabio, Brazil), followed by detection of HCV-RNA by means of nested RT-PCR amplification on a second plasma sample. The tests were performed in accordance with the manufacturers' instructions, or as previously described ${ }^{15}$. A serodiagnosis of HTLV infection was established whenever seroreactivity was demonstrated using the commercially available enzyme immunoassays (Organon Technika, USA; Embrabio, Brazil), and was confirmed using Western blot tests (WB 2.3; WB 2.4, Diagnostic Biotechnology, Singapore), following the manufacturers' instructions. Based on reactivity to type-specific recombinant peptides encoded by the gag and $e n v$ regions of the HTLV proviral genome, the patients were discriminated as presenting either HTLV-1 or HTLV-2 infection, as recommended by the Brazilian Ministry of Health ${ }^{23}$. HTLV infection was further confirmed by nested PCR amplification of tax sequences of the proviral DNA from peripheral blood mononuclear cells (PBMC), as previously described ${ }^{17} 1837$.

For the histopathological evaluation, patients were eligible only if their liver biopsy specimen was considered suitable for grading and staging tissue abnormalities ${ }^{8}$.

Study procedures. Patients were invited to take part in the survey at their regular medical follow-up visits to the outpatient clinic, between 2004 and 2006. Alternatively, those who did not attend the clinic during this period were contacted by telephone.
If the patients agreed to participate, they were admitted to the study after giving their written consent. They then underwent a standardized interview with the research team, for epidemiological and clinical data to be obtained. In addition, the medical files were reviewed to collect laboratory and liver histopathological data. For analytical purposes, we used the results from hematological and liver function tests that had been performed less than 60 days before the liver biopsy procedure and before any therapeutic intervention for HCV liver disease. Throughout the data collection, confidentiality and patients' anonymity were ensured. The study protocol was approved by the institutional review board.

The variables of interest included:

- sociodemographic characteristics: gender, age, skin color, marital status, schooling and place of birth;

- habits: smoking and alcohol consumption;

- risk factors for acquisition of sexually-transmitted or bloodborne infections: history of intravenous drug use, history of inhaled cocaine use, history of blood transfusion, tattooing, acupuncture, sexual partnership with an IDU or with someone who reported hepatitis, and number of sexual partners in the year preceding admission to the study;

- clinical data: signs and symptoms of liver disease (jaundice, ascites, epistaxis, palmar erythema and spiders), malaise, abdominal pain, skin abnormalities, neurological symptoms (paresis and paresthesia), hepatomegaly or splenomegaly on clinical examination;

- results from laboratory tests: hemoglobin, hematocrit, white cell and platelet counts, serum liver enzyme concentrations (AST, ALT and GGT), alkaline phosphatase, serum bilirubin, albumin and gamma globulin concentrations and prothrombin time.

With regard to liver histopathological features, the data collection was based on a standardized review of all biopsy specimens. This was carried out by a single skilled professional, using Ishak's diagnostic criteria ${ }^{19}$.

Statistical analysis. After setting up a database using the Microsoft Excel 2002 software, the patients in the different study groups (HCV/HTLV-1, HCV/HTLV-2 and HCV) were initially compared by means of bivariate analysis. The $\chi^{2}$ test was used to compare the proportions of individuals with variables of interest among the different study groups and the Kruskal-Wallis tests was used to compare continuous variables ${ }^{19}$. Subsequently, Fischer's linear discriminant analysis was carried out to define classifying functions containing the variable set that together would best distinguish the patients in the three study groups ${ }^{20}$. Variables that exhibited p-values $<0.20$ in bivariate analysis were chosen for multivariate analysis; age and gender were additionally included. The evaluation of the model's discriminating accuracy was then checked by cross-validation, using the leave-one-out technique ${ }^{70}$. In this procedure, each study subject was analyzed as external to the model and was classified again by applying his/her data to the new classifying functions that had been set up using the other (n-1) study subjects. The discriminating accuracy of the model was considered high when the cross-validation procedure yielded the right classification 
in more than $75 \%$ of the cases $^{10}$. The statistical analysis was performed using the SPSS version 13.0 software package, with a $5 \%$ significance level.

\section{RESULTS}

The study cohort comprised 85 patients, diagnosed as follows: 24 (28.3\%) HCV/HTLV-1 coinfected individuals, 6 (7\%) with HCV/HTLV-2 coinfection and 55 (64.7\%) infected with HCV alone. Most (53\%) patients were male and aged from 20 to 59 (mean age, 40$)$. White $(71.8 \%)$ and married (51.8\%) subjects, with eight to ten years of schooling $(45.9 \%)$, born in the State of São Paulo (71.8\%), predominated (Table 1). With regard to

\section{TABLE 1}

Comparison of 24 HCV/HTLV-1 coinfected, six HCV/HTLV 2 coinfected and 55 HCVinfected patients with regard to sociodemographic features. Hospital das Clinicas, School of Medicine, University of São Paulo, 1993-2005.

\begin{tabular}{|c|c|c|c|c|c|c|c|}
\hline \multirow[b]{3}{*}{ Variable } & \multicolumn{6}{|c|}{ Group } & \multirow[b]{3}{*}{$\mathrm{P}$} \\
\hline & \multicolumn{2}{|c|}{$\mathrm{HCV}$} & \multicolumn{2}{|c|}{ HCV/HTLV-1 } & \multicolumn{2}{|c|}{ HCV/HTLV-2 } & \\
\hline & $\mathrm{n}$ & $\%$ & $\mathrm{n}$ & $\%$ & $\mathrm{n}$ & $\%$ & \\
\hline Gender & & & & & & & 0.98 \\
\hline male & 29 & 52.7 & 13 & 54.2 & 3 & 50.0 & \\
\hline female & 26 & 47.3 & 11 & 45.8 & 3 & 50.0 & \\
\hline Age (years) & & & & & & & 0.18 \\
\hline $18-29$ & 17 & 30.9 & 5 & 20.8 & 1 & 16.7 & \\
\hline $30-39$ & 9 & 16.4 & 6 & 25.0 & 4 & 66.6 & \\
\hline $40-49$ & 19 & 34.5 & 9 & 37.5 & 1 & 16.7 & \\
\hline$\geq 50$ & 10 & 18.2 & 4 & 16.7 & - & - & \\
\hline
\end{tabular}

\begin{tabular}{|c|c|c|c|c|c|c|c|}
\hline Color & & & & & & & 0.50 \\
\hline white & 39 & 70.9 & 17 & 70.8 & 5 & 83.3 & \\
\hline mulatto & 13 & 23.6 & 3 & 12.5 & 1 & 16.7 & \\
\hline black & 3 & 5.5 & 3 & 12.5 & - & - & \\
\hline yellow & - & - & 1 & 4.2 & - & - & \\
\hline Marital status & & & & & & & 0,59 \\
\hline married & 30 & 54.5 & 10 & 41.6 & 4 & 66.6 & \\
\hline single & 14 & 25.5 & 9 & 37.5 & 1 & 16.7 & \\
\hline divorced & 11 & 20.0 & 4 & 16.7 & 1 & 16.7 & \\
\hline widowed & - & - & 1 & 4.2 & - & - & \\
\hline Schooling (years) & & & & & & & 0.56 \\
\hline$\leq 7$ & 19 & 34.5 & 6 & 25.0 & 1 & 16.7 & \\
\hline $8-10$ & 22 & 40.0 & 14 & 58.3 & 3 & 50.0 & \\
\hline$\geq 11$ & 14 & 25.5 & 4 & 16.7 & 2 & 33.3 & \\
\hline State of birth & & & & & & & 0.08 \\
\hline São Paulo & 35 & 63.6 & 21 & 87.5 & 5 & 83.3 & \\
\hline others & 20 & 36.4 & 3 & 12.5 & 1 & 16.7 & \\
\hline Smoking* & & & & & & & 0.179 \\
\hline no & 38 & 70.4 & 12 & 50.0 & 3 & 50.0 & \\
\hline yes & 16 & 29.6 & 12 & 50.0 & 3 & 50.0 & \\
\hline Alcohol consumption & & & & & & & 0.009 \\
\hline no & 40 & 72.7 & 12 & 50.0 & 1 & 16.7 & \\
\hline yes & 15 & 27.3 & 12 & 50.0 & 5 & 83.3 & \\
\hline
\end{tabular}

*data missing for one patient from the HCV group

HCV: hepatitis C virus, HTLV-1: human T-lymphotropic virus type 1, HTLV-2: human T-lymphotropic virus type 2 . smoking, no statistically significant difference was seen among the study groups. In contrast, reported alcohol consumption was significantly more frequent among the patients in the HCV/HTLV-2 group $(\mathrm{p}=0.009)$.

Table 2 summarizes the exposure to sexually-transmitted or blood-borne infections among the patients in the different study groups. Reported intravenous drug use, inhaled cocaine use and sexual partnership with an IDU were significantly more frequent among the patients in the HCV/HTLV-2 group, compared with the other groups. Sexual partnership with an individual with hepatitis, however, was more often seen in the HCV group.

Regarding clinical complaints, abdominal pain was reported more frequently by the patients in the HCV group $(25.5 \%$, $\mathrm{p}=0.024)$, compared with $16.7 \%$ of their counterparts in the HCV/HTLV-2 group and none of the patients with HCV/HTLV-1 coinfection. No significant differences were noticed among the

\section{TABLE 2}

Comparison of 24 HCV/HTLV-1 coinfected, six HCV/HTLV 2 coinfected and 55 HCVinfected patients with regard to risk factors for virus acquisition. Hospital das Clinicas, School of Medicine, University of São Paulo, 1993-2005.

\begin{tabular}{|c|c|c|c|c|c|c|c|}
\hline \multirow[b]{3}{*}{ Variable } & \multicolumn{6}{|c|}{ Group } & \multirow[b]{3}{*}{$\mathrm{P}$} \\
\hline & \multicolumn{2}{|c|}{$\mathrm{HCV}$} & \multicolumn{2}{|c|}{ HCV/HTLV-1 } & \multicolumn{2}{|c|}{ HCV/HTLV-2 } & \\
\hline & $\mathrm{n}$ & $\%$ & $\mathrm{n}$ & $\%$ & $\mathrm{n}$ & $\%$ & \\
\hline Intravenous drug use & & & & & & & $<0.001$ \\
\hline no & 53 & 96.4 & 20 & 83.3 & 2 & 33.3 & \\
\hline yes & 2 & 3.6 & 4 & 16.7 & 4 & 66.7 & \\
\hline Inhaled cocaine use & & & & & & & 0.022 \\
\hline no & 41 & 74.5 & 21 & 87.5 & 2 & 33.3 & \\
\hline yes & 14 & 25.5 & 3 & 12.5 & 4 & 66.7 & \\
\hline Sexual partnership with IDU* & & & & & & & $<0.001$ \\
\hline no & 53 & 96.4 & 17 & 77.3 & - & - & \\
\hline yes & 2 & 3.6 & 5 & 22.7 & 3 & 100.0 & \\
\hline Sexual partner with hepatitis**k & & & & & & & 0.001 \\
\hline no & 50 & 90.9 & 16 & 94.1 & 4 & 100.0 & \\
\hline yes & 5 & 9.1 & 1 & 5.9 & - & - & \\
\hline Recipient of blood transfusion & & & & & & & 0.332 \\
\hline no & 32 & 58.2 & 12 & 50.0 & 5 & 83.3 & \\
\hline yes & 23 & 41.8 & 12 & 50.0 & 1 & 16.7 & \\
\hline Tattooing & & & & & & & 0.061 \\
\hline no & 51 & 92.7 & 23 & 95.8 & 4 & 66.7 & \\
\hline yes & 4 & 7.3 & 1 & 4.2 & 2 & 33.3 & \\
\hline Acupuncture & & & & & & & 0.349 \\
\hline no & 48 & 87.3 & 23 & 95.8 & 6 & 100.0 & \\
\hline yes & 7 & 12.7 & 1 & 4.2 & - & - & \\
\hline \multicolumn{8}{|l|}{ Number of sexual partners } \\
\hline in the previous year**** & & & & & & & 0.224 \\
\hline 1 & 50 & 92.6 & 19 & 79.2 & 5 & 83.3 & \\
\hline$>1$ & 4 & 7.4 & 5 & 20.8 & 1 & 16.7 & \\
\hline
\end{tabular}

*data missing for 7 and 2 patients from the HCV/HTLV-1 and HCV/HTLV-2 groups, respectively.

**data missing for 2 and 3 patients from the HCV/HTLV-1 and HCV/HTLV-2 groups, respectively.

****data missing for one patient from the HCV group

HCV: hepatitis C virus, HTLV-1: human T-lymphotropic virus type 1, HTLV-2: human T-lymphotropic virus type 2, IDU: intravenous drug user. 
study groups regarding the frequency of signs and symptoms of liver disease (jaundice, ascites, epistaxis, palmar erythema, spiders, hepatomegaly or splenomegaly), reported malaise or skin and neurological abnormalities on clinical examination.

Laboratory investigations yielded significantly higher median platelet counts in HCV/HTLV-1 or HCV/HTLV-2 coinfected individuals, compared with patients in the HCV group $(\mathrm{p}=0.015)$. Conversely, higher median serum AST, ALT and GGT concentrations were seen in HCV-infected patients $(\mathrm{p}=0.047, \mathrm{p}=0.011$ and $\mathrm{p}<0.001$, respectively).

Seventy-five patients ( $88.2 \%$ of the study cohort) were compared regarding their liver histopathological features. Although most of them exhibited abnormal findings in their liver biopsy specimens, no statistically significant differences were seen among the patients in the different study groups (Table 3).

\section{TABLE 3}

Comparison of 24 HCV/HTLV-1 coinfected, six HCV/HTLV 2 coinfected and 55 HCVinfected patients with regard to liver histopathological findings. Hospital das Clinicas, School of Medicine, University of São Paulo, 1993-2005.

\begin{tabular}{|c|c|c|c|c|c|c|c|}
\hline \multirow[b]{3}{*}{ Variable } & \multicolumn{6}{|c|}{ Group } & \\
\hline & \multicolumn{2}{|c|}{$\mathrm{HCV}$} & \multicolumn{2}{|c|}{ HCV/HTLV-1 } & \multicolumn{2}{|c|}{ HCV/HTLV-2 } & \multirow[b]{2}{*}{$\mathrm{P}$} \\
\hline & $\mathrm{n}$ & $\%$ & $\mathrm{n}$ & $\%$ & $\mathrm{n}$ & $\%$ & \\
\hline Fibrosis (score) & & & & & & & 0.763 \\
\hline$<3$ & 37 & 67.3 & 11 & 68.8 & 2 & 50.0 & \\
\hline$\geq 3$ & 18 & 32.7 & 5 & 31.2 & 2 & 50.0 & \\
\hline Necroinflammatory activity (score) & & & & & & & 0.256 \\
\hline $\operatorname{minimal}(0-6)$ & 20 & 36.4 & 4 & 25.0 & - & - & \\
\hline mild/moderate ( $7-12)$ & 35 & 63.6 & 12 & 75.0 & 4 & 100.0 & \\
\hline \multicolumn{8}{|l|}{ Portal inflammation } \\
\hline present $($ score $\geq 1$ ) & 55 & 100.0 & 16 & 100.0 & 4 & 100.0 & \\
\hline \multicolumn{8}{|l|}{ Periportal or periseptal } \\
\hline interface hepatitis & & & & & & & 0.547 \\
\hline absent & 18 & 32.7 & 3 & 18.8 & 1 & 25.0 & \\
\hline present & 37 & 67.3 & 13 & 81.2 & 3 & 75.0 & \\
\hline Lobular necrosis & & & & & & & 0.145 \\
\hline absent & 1 & 1.8 & 2 & 12.5 & - & - & \\
\hline present & 54 & 98.2 & 14 & 87.5 & 4 & 100 & \\
\hline
\end{tabular}

After Fischer's discriminant analysis, the following discriminating functions were defined for each of the study groups:

$\mathbf{y}_{\text {HCV }}=-6.558+0.605$ (IDU) +0.045 (sexual partnership with someone with reported hepatitis) +4.976 (gender) +1.485 (age group)

$\mathbf{y}_{\text {HCV/HTLV-1 }}=-7.178+1.636$ (IDU) +1.437 (sexual partnership with someone with reported hepatitis) +4.942 (gender) +1.512 (age group)

$\mathbf{y}_{\text {HCV/HTLV-2 }}=-9.685+9.265$ (IDU) +0.849 (sexual partnership with someone with reported hepatitis) +6.303 (gender) +0.487 (age group)

IDU (yes $=0$, no $=1$ ); sexual partnership with someone with reported hepatitis (yes $=0$, no $=1) ;$ gender $($ male $=0$, female $=1) ;$ age group $(18$ to 29 years $=0 ; 30$ to 39 years $=1 ; 40$ to 49 years $=2 ; 50$ years or more $=3$ )
Cross-validation of the model using the leave-one-out technique showed that even though the discriminating functions were able to classify $67.1 \%$ of the patients in the study cohort correctly, their performance differed in each of the three study groups. The discriminating accuracy was high $(87.3 \%)$ for the HCV group-defining function, but intermediate (66.7\%) for the HCV/HTLV-2 function. In contrast, the HCV/HTLV-1 group function exhibited low (20.8\%) discriminating accuracy.

\section{DISCUSSION}

HCV/HTLV coinfections are a matter of particular concern with regard to the clinical management of patients with infectious diseases, not only because of the epidemiological importance of these viral infections in Brazil, but also because of the possible pathogenetic interactions among them. However, the epidemiological, clinical and laboratory features of these coinfections have been overlooked so far, or alternatively, have been investigated without clear distinction of the HTLV type (HTLV1 or HTLV-2) that is involved. By means of Fischer's discriminating analysis, our study investigated epidemiological, clinical and laboratory diagnostic tools that might better differentiate HCV/HTLV coinfected individuals from their HCV-infected counterparts.

Among the variables that were defined as useful for discriminating between coinfected individuals, self-reporting of intravenous drug use was particularly relevant. It was more often found among HCV/HTLV-2 coinfected patients, thus suggesting that this route was important for acquisition of this retrovirus among the study population, as previously reported in other epidemiological contexts. De la Fuente et al. found that HTLV-2 infection was strongly associated with injectable drug use among young Spanish addicts, as well as with HIV and HCV coinfections ${ }^{13}$. Likewise, in a prevalence study on HTLV infection among American women, HTLV-2 infection was shown to be significantly associated with injectable drug use, regardless of HIV coinfection ${ }^{36}$. Nonetheless, previous Brazilian studies presented conflicting data with regard to the association between intravenous drug use and HTLV-2 infection. Although some investigators have indicated an epidemiologic association ${ }^{14}$, studies conducted more recently have highlighted the leading role of HTLV-1 among HTLV-infected drug addicts in Bahia ${ }^{11}$. Our results reinforce the idea that HTLV-2 infection is possibly spread by means of injectable drug use, and thus suggest that the way in which this retrovirus circulates may vary between different Brazilian geographic regions.

Regarding sexual activity, we found that the patients in the different study groups differed in their reports about having a sexual partner with hepatitis. Since the role of sexual transmission in the epidemiology of HCV infection is still controversial ${ }^{34}$, we hypothesize that the routine counseling that was provided for individuals with HTLV, to encourage them to adopt safer sexual practices $^{623}$, may have accounted for the observed difference, to a certain extent. Sexual partnership with an IDU was significantly more frequent among the patients in the HCV/HTLV-2 group, thus suggesting that they were at greater risk of HTLV-2 acquisition through sexual means. However, even though HTLV-1 and 
HTLV-2 have been acknowledged to be sexually-transmitted agents $^{263538}$, recent evidence has suggested that transmission is not particularly associated with any of the HTLV types ${ }^{30}$. Alternatively, and speculatively, the increased risk of HTLV-2 acquisition among these individuals may have been due to non-reported IDU, as previously described in a serological survey of HCV coinfection among people living with HIV in Santos, Brazil ${ }^{34}$.

Use of inhaled cocaine was significantly more often reported among the patients in the HCV/HTLV-2 group. Nevertheless, since there is no evidence that such practices add to the risk of HTLV-2 acquisition, and because no information was available about the sharing of instruments for inhalation ${ }^{21}$, we believe that this might be a confounder. Based on reports in the literature that indicate that alcohol consumption is high among intravenous drug users ${ }^{2}$, we suppose that this association may have contributed towards our finding of a higher frequency of alcohol consumption among HCV/HTLV-2 coinfected individuals from our cohort.

The chronic course of HCV infection, as well as the fact that HTLV infection is most often asymptomatic throughout life, may have impaired the statistical power of the clinical variables regarding their ability to differentiate patients in the different study groups, except for abdominal pain. This complaint was more often reported by patients in the HCV group. Although this symptom is frequently reported by HCV-infected individuals ${ }^{22}$, pathogenetic mechanisms that might justify different frequencies of abdominal pain between HCV-infected and HCV/HTLV coinfected patients could not be identified.

Laboratory investigations demonstrated lower platelet counts among the HCV-infected patients, compared with the coinfected individuals. In contrast, although the aminotransferase and GGT levels were high in patients in all of the groups, they were significantly higher in the HCV group. This discrepancy might be due to HCV disease that was more advanced. Nevertheless, this was not supported by histopathological data. Alternatively, differences in platelet counts could be ascribed to HTLV-driven thrombocytogenesis, as hypothesized by Murphy et $\mathrm{a}^{25}$ from an evaluation on hematological disorders among asymptomatic carriers of retroviral infection who were volunteer blood donors at different centers in the USA.

In our study, the analysis of liver histopathological abnormalities revealed higher frequencies of less severe fibrosis (score < 3) among the HCV (67.3\%) and HCV/HTLV-1 (68.8\%) individuals, compared with the HCV/HTLV-2 individuals (50\%), although without statistical significance. Although length of time since HCV infection and age at the first biopsy procedure have been recognized as associated with progression of HCV-related fibrosis ${ }^{31}$, these variables were not useful for clarifying differences in the histopathological data in our study. We found no significant age differences among the patients in the different study groups at the time when they underwent liver biopsy. Moreover, the crosssectional design of our study precluded recognition of length of time with HCV infection and of the precise chronology of events among coinfected HCV/HTLV individuals. In contrast to these methodological constraints, Japanese longitudinal studies have provided evidence of accelerated HCV disease progression among
HCV/HTLV-1 coinfected patients ${ }^{4}$. Follow-up of our patients, with inclusion of more HCV/HTLV-2 individuals, is thus warranted in order to clarify the impact of HTLV coinfection on the progression of HCV disease.

Another limitation of our study resulted from the fact that there were few HCV/HTLV coinfected individuals among the patients seen at the clinic, who were not also HBV or HIV-coinfected ${ }^{32} 33$. Since these viruses share their means of transmission, multiple coinfections are often identified among individuals at high risk of viral exposure.

Despite these limitations, we believe our study has improved the understanding of the epidemiological, clinical, laboratory and histopathological features of HCV/HTLV coinfection and has contributed towards better identification of distinctive features for discriminating between HCV-infected and HCV/HTLV coinfected individuals. Applying this information to the routine care of HCVinfected patients may help the healthcare team clarify when HTLV serological screening and counseling should be implemented for these individuals.

\section{ACKNOWLEDGEMENTS}

The authors are grateful to CAPES and CNPq (Brazilian Ministries of Education and of Science and Technology).

\section{REFERENCES}

1. Agresti A. Categorical data analysis. Wiley, New York, 1990.

2. Anderson BJ, Gogineni A, Charuvastra A, Longabaugh R, Stein MD. Adverse drinking consequences among alcohol abusing intravenous drug users. Alcoholism, Clinical and Experimental Research 25:41-45, 2001.

3. Bedossa P, Poynard T. An algorithm for the grading of activity in chronic hepatitis C. The METAVIR Cooperative Study Group. Hepatology 24:289-293, 1996.

4. Boschi-Pinto C, Stuver S, Okayama A, Trichopoulos D, Orav EJ, Tsubouchi H, Mueller N. A follow-up study of morbidity and mortality associated with hepatitis $\mathrm{C}$ virus infection and its interaction with HTLV-I in Miyazaki, Japan. The Journal of Infectious Diseases 181:35-41, 2000.

5. Carneiro-Proietti AB, Lima-Martins MV, Passos VM, Carmo RA, Pinheiro SR, Rocha PR, Proietti FA, Ferreira PC, Rocha VG. Presence of human immunodeficiency virus (HIV) and T-lymphotropic virus type I and II (HTLV-I/II) in a haemophiliac population in Belo Horizonte, Brazil, and correlation with additional serological results. Haemophilia 4:47-50, 1998.

6. Centers for Disease Control and Prevention and the U.S.P.H.S. Working Group. Guidelines for counseling persons infected with human T-lymphotropic virus type I (HTLV-I) and type II (HTLV-II). Annals of Internal Medicine 118:448-454, 1993.

7. Chan YH. Discriminant analysis. Singapore Medical Journal 46:54-62, 2005.

8. Colloredo G, Guido M, Sonzogni A, Leandro G. Impact of liver biopsy size on histological evaluation of chronic viral hepatitis: the smaller the sample, the milder the disease. Journal of Hepatology 39:239-244, 2003.

9. Conover WJ. Practical nonparametric statistics. $2^{\text {nd }}$ edition Wiley, New York, 1980.

10. Dong B, Xie YQ, Chen K, Wang T, Tang W, You WC, Li JY. Differences in biological features of gastric dysplasia, indefinite dysplasia, reactive hyperplasia and discriminant analysis of these lesions. World Journal of Gastroenterology 11:3595-3600, 2005.

11. Dourado I, Andrade T, Galvão-Castro B. HTLV-I in Northeast Brazil: differences for male and female injecting drug users. Journal of Acquired Immune Deficiency Syndromes and Human Retrovirology 19:426-429, 1998. 
12. Ferreira Jr OC, Vaz RS, Carvalho MB, Guerra C, Fabron AL, Rosemblit J, Hamerschlak N. Human T-lymphotropic virus type I and type II infections and correlation with risk factors in blood donors from São Paulo, Brazil. Transfusion 35:258-263, 1995.

13. Fuente L, Toro C, Soriano V, Brugal MT, Vallejo F, Barrio G, Jimenez V, Silva T, Project Itinere Working Group. HTLV infection among young injection and noninjection heroin users in Spain: prevalence and correlates. Journal of Clinical Virology 35:244-249, 2006

14. Gabbai AA, Bordin JO, Vieira-Filho JP, Kuroda A, Oliveira AS, Cruz MV, Ribeiro AA, Delaney SR, Henrard DR, Rosario J. Selectivity of human T lymphotropic virus type-1 (HTLV-1) and HTLV-2 infection among different populations in Brazil. The American Journal of Tropical Medicine and Hygiene 49:664-671, 1993.

15. Garson JA, Ring C, Tuke P, Tedder RS. Enhanced detection by PCR of hepatitis C virus RNA. Lancet 336:878-879, 1990b.

16. Garson JA, Tedder RS, Briggs M, Tuke P, Glazebrook, JA, Trute A, Parker D, Barbara JAJ, Contreras M, Aloysius S. Detection of hepatitis C viral sequences in blood donations by "nested" polymerase chain reaction and prediction of infectivity. Lancet 335:1418-1422, 1990a.

17. Heneine W, Khabbaz RF, Lal RB, Kaplan JE. Sensitive and specific polymerase chain reaction assays for diagnosis of human T-cell lymphotropic virus type I (HTLV-I) and HTLV-II infections in HTLV-I/II-seropositive individuals. Journal of Clinical Microbiology 30:1605-1607, 1992.

18. Innis MA, Gelfand DH, Sninsky JJ, White T. PCR-Protocols: a guide to methods and applications. Academic Press, New York, 1990

19. Ishak K, Baptista A, Bianchi L, Callea F, De Groote J, Gudat F, Denk H, Desmet V, Korb G, Macsween RNM, Phillips MJ, Portmann BG, Poulsen H, Scheuer PJ, Schmidt M, Thaler H. Histological grading and staging of chronic hepatitis. Journal of Hepatology 22:696-699, 1995.

20. Johnson RA, Wichern DW. Applied multivariate statistical analysis. $4^{\text {th }}$ edition. Prentice Hall, New Jersey, 1998

21. Koblin BA, Factor SH, Wu Y, Vlahov D. Hepatitis C virus infection among noninjecting drug users in New York City. Journal of Medical Virology 70:387$390,2003$.

22. Lang CA, Conrad S, Garrett L, Battistutta D, Cooksley WG, Dunne MP, Macdonald GA. Symptom prevalence and clustering of symptoms in people living with chronic hepatitis C infection. Journal of Pain and Symptom Management 31:335-344, 2006.

23. Ministério da Saúde. Guia de manejo clínico do HTLV. Normas e Manuais TécnicosSérie Manuais; $\mathrm{n}^{\circ} 3$-CN-DST e Aids: Brasília, 2003.

24. Morimoto HK, Caterino-De-Araujo A, Morimoto AA, Reiche EM, Ueda LT, Matsuo T, Stegmann JW, Reiche FV. Seroprevalence and risk factors for human T cell lymphotropic virus type 1 and 2 infection in human immunodeficiency virus-infected patients attending AIDS referral center health units in Londrina and other communities in Parana, Brazil. AIDS Research and Human Retroviruses 21:256-262, 2005.

25. Murphy EL, Glynn S, Watanabe K, Fridey J, Smith J, Sacher R, Wright D, Schreiber G, Luban N. Laboratory test differences associated with HTLV-I and HTLV-II infection. Retrovirus Epidemiology Donor Study Investigators. Journal of Acquired Immune Deficiency Syndromes and Human Retrovirology 17:332-338,1998.

26. Nakashima K, Ikematsu H, Hayashi J, Kishihara Y, Mutsutake A, Kashiwagi S. Intrafamilial transmission of hepatitis-C virus among the population of an endemic area of Japan. The Journal of The American Medical Association 274:1459-1461, 1995.

27. Okayama A, Maruyama T, Tachibana N, Hayashi K, Kitamura T, Mueller N Tsubouchi H. Increased prevalence of HTLV-I infection in patients with hepatocellular carcinoma associated with hepatitis $\mathrm{C}$ virus. Japanese Journal of Cancer Research 86:1-4, 1995.

28. Pando MA, Bautista CT, Maulen S, Duranti R, Marone R, Rey J, Vignoles M, Eirin ME, Biglione MM, Griemberg G, Montano SM, Carr JK, Sanchez JL, Avila MM. Epidemiology of Human Immunodeficiency Virus, Viral Hepatitis (B and C), Treponema pallidum, and Human T-Cell Lymphotropic I/II Virus Among Men Who Have Sex With Men in Buenos Aires, Argentina. Sexually Transmitted Diseases 33:307-313, 2006.

29. Porto AF, Santos SB, Alcantara L, Guerreiro JB, Passos J, Gonzalez T, Neva F, Gonzalez D, Ho JL, Carvalho EM. HTLV-1 modifies the clinical and immunological response to schistosomiasis. Clinical and Experimental Immunology 137:424-429, 2004

30. Roucoux DF, Wang B, Smith D, Nass CC, Smith J, Hutching ST, Newman B, Lee TH, Chafets DM, Murphy EL; HTLV Outcomes Study Investigators. A prospective study of sexual transmission of human T lymphotropic virus (HTLV)-I and HTLV-II. The Journal of Infectious Diseases 191:1490-1497, 2005.

31. Ryder SD, Irving WL, Jones DA, Neal KR, Underwood JC, Trent Hepatitis C Study Group. Progression of hepatic fibrosis in patients with hepatitis C: a prospective repeat liver biopsy study. Gut 53:451-455, 2004.

32. Salles NA, Sabino EC, Barreto CC, Barreto AM, Otani MM, Chamone DF. The discarding of blood units and the prevalence of infectious diseases in donors at the Pro-Blood Foundation/Blood Center of São Paulo, São Paulo, Brazil. Revista Panamericana de Salud Pública 13:111-116, 2003.

33. Segurado AA, Malaque CM, Sumita LM, Pannuti CS, Lal RB. Laboratory characterization of human T cell lymphotropic virus types 1 (HTLV-1) and 2 (HTLV-2) infections in blood donors from Sao Paulo, Brazil. The American Journal of Tropical Medicine and Hygiene 57:142-148, 1997.

34. Segurado AC, Braga P, Etzel A, Cardoso MR. Hepatitis C virus coinfection in a cohor of HIV-infected individuals from Santos, Brazil: seroprevalence and associated factors. AIDS Patient Care and STDs 18:135-143, 2004

35. Stuver SO, Tachibana N, Okayama A, Shioiri S, Tsunetoshi Y, Tsuda K, Mueller NE. Heterosexual transmission of human T cell leukemia/lymphoma virus type among married couples in southwestern Japan: an initial report from the Miyazaki Cohort Study. The Journal of Infectious Diseases 167:57-65, 1993.

36. Telzak EE, Hershow R, Kalish LA, Hardy Jr WD, Zuckerman E, Levine A, Delapenha R, DeHovitz J, Greenblatt RM, Anastos K. Seroprevalence of HTLV-I and HTLV-I among a cohort of HIV-infected women and women at risk for HIV infection. Women's Interagency HIV Study. Journal of Acquired Immune Deficiency Syndromes and Human Retrovirology 19:513-518, 1998.

37. Tuke PW, Luton P, Garson JA. Diferential diagnosis of HTLV-I and HTLV-II infection by restriction enzyme analysis of "nested" PCR products. Journal of Virological Methods 40:163-174, 1992.

38. Vitek CR, Gracia FI, Giusti R, Fukuda K, Green DB, Castillo LC, Armien B, Khabbaz RF, Levine PH, Kaplan JE, et al. Evidence for sexual and mother-to-child transmission of human T lymphotropic virus type II among Guaymi Indians, Panama. The Journal of Infectious Diseases 171:1022-1026, 1995. 